\title{
THE USE OF THE DESIGN FMEA METHOD ON THE EXAMPLE OF A GUTTERING SYSTEM
}

\author{
Andrzej DZIERWA ${ }^{1}$, Ryszard RADWAŃSKI ${ }^{2}$, Andrzej PACANA $^{3 *}$ \\ ${ }^{1}$ Rzeszow University of Technology, Faculty of Mechanical Engineering and Aeronautics; \\ adzierwa@prz.edu.pl, ORCID: 0000-0003-4545-1748 \\ ${ }^{2}$ War Studies University, Faculty of Management and Command; ryszard.radwanski@vip.onet.pl, \\ ORCID: 0000-0002-2100-6845 \\ ${ }^{3}$ Rzeszow University of Technology, Faculty of Mechanical Engineering and Aeronautics; app@prz.edu.pl, \\ ORCID: 0000-0003-1121-6352 \\ * Correspondence author
}

Purpose: The main aim of the paper is to identify, evaluate and improve the factors that are responsible for the reliable operation of the guttering system using the Failure Mode and Effects Analysis (FMEA) methodology.

Design/methodology/approach: To achieve the planned goal, the FMEA method was used. This is one of the suitable techniques of reliability modelling used to investigate the failure behaviour of a products and processes. The article presents the use of design FMEA on the example of a guttering system that is produced in one of the companies in the Podkarpackie province. In order to do this, potential defects and their effects have been identified. Later, the control methods used in the company were specified. The frequency of potential defects was then estimated, as well as their significance and possibility of detection.

Findings: The design FMEA method allowed the authors to reveal defects, including critical defects, which may significantly affect the construction of a guttering system. The defects and their root causes were identified, and a proposal for corrective and preventive actions was suggested.

Originality/value: An original solution of a guttering system that is currently in production in the Podkarpackie province was tested. This analysis should contribute to improving the quality of products manufactured here.

Keywords: Failure Modes and Effects Analysis (FMEA), guttering system, quality improvement.

Category of the paper: Research paper. 


\section{Introduction}

The roof of a building and the roof drainage system are the basic means of protecting a structure against the ingress of water during rainfall (Verstraten et al., 2017). Failures of the roof drainage system resulting from high-intensity events can cause significant damage to the building and, consequently, high costs for subsequent repairs. Typical elements of a roof drainage system include building roofing, guttering system, sumps and downpipes (Blong, 2004; Spekkers et al., 2014). The most important task for guttering systems is to ensure the correct and complete drainage of rainwater accumulated on the roof surface. This is particularly important in the case of sudden, heavy rainfalls (Tavukcuoglu et al., 2007). An important factor is also to ensure the appropriate aesthetics of the building, as well as the possibility of safe, quick and easy installation (Półtorak, 2010). In addition, we currently have a selection of materials from which guttering systems can be made. They differ in properties and purpose. Therefore, when choosing a specific type of guttering system, the conditions in which it will be used should be taken into account. The most popular materials used for guttering systems include PVC, steel, titanium-zinc, copper and aluminium (Florczak, 2014).

The most popular products on the Polish market are guttering systems made of PVC, thanks to its competitive price and durability. The advantage of these systems also includes resistance to mechanical damage, as well as weather conditions. Polyvinyl chloride gutters are also characterised by low surface roughness values, which makes it easier for both water and snow to flow down. Steel gutters are one of the most durable materials. Their functionality is often expected even up to 100 years of operation. Steel guttering systems are characterised by very good tolerance of temperature in the range from -40 to even +100 degrees Celsius. In this, range they maintain all their properties. Steel gutters are also resistant to corrosion and are often additionally protected with protective layers. Guttering systems made of materials such as titanium-zinc are characterised by high durability, and at the same time, they guarantee the attractive appearance of the whole system. These systems also provide very high resistance to changing weather conditions. Copper guttering systems are considered the most durable in the world, but their main disadvantage is the high price. In turn, the biggest advantages of aluminium systems are durability and total corrosion resistance (Florczak, 2014).

In addition to the material, when choosing an appropriate guttering system, everyone should pay attention to the technical aspects of the solutions used to connect individual elements so that they ensure maximum leak resistance. Leakage of joints caused by the variability of atmospheric conditions is among the most frequently reported defects in guttering systems. The leakage effect visible to end users occurs in the form of wet walls, which consequently leads to the destruction of building façades.

This article presents a design FMEA method of a selected guttering system produced in the Podkarpackie providence as one of the methods used by a company to reduce or avoid the risk of producing a defective product. 


\section{Characteristic of the FMEA method}

FMEA stands for Failure Modes and Effects Analysis, although other translations of the original name can also be found (Gerber, 2017). The first uses of FMEA occurred in the 1960s in the space industry, then in the 1970s in the military industry and later in the automotive industry. At present, the method is widely used in various processes, not only manufacturing, but also in services (Hąbek, 2017). A design FMEA estimates potential product failures and the effects of these failures to the end user, while a manufacturing or process FMEA estimates the variables that can affect the quality of a process. The main goal of a service FMEA is to prevent the misuse or misrepresentation of the tools and materials used in servicing a product. The FMEA method is used to recognise failure modes together with the risk of their occurrence, as well as the consequences of their occurrence and elimination (Rusiecki, 2018). The FMEA method requires a detailed knowledge of the analysed object, because it is necessary to determine what potential defects may occur during the manufacturing of the product. In addition, the method of organising the process or construction, control methods used so far, applied technologies, ways of joining individual components, etc. should also be taken into account. Practical use of the FMEA method requires not only proper knowledge of this method, but also very accurate orientation in the subject being analysed (Gerber, 2017). The simplified scheme of the FMEA analysis is presented in Figure 1.

The prioritisation of undesirable states is done using a risk priority number (RPN) to determine the impact of risk (severity), the possibility of risk (occurrence) and risk opportunities (detection). Hence RPN = OSD:

- $\mathrm{O}$ (probability of occurrence of the defect) - number of defects;

- $\mathrm{S}$ (importance of the defect for the customer) - significance of the defect;

- D (potentiality of defect detection by the manufacturer) - possibility of the detection.

The most commonly used range of criteria is a 1-10 scale (van Leeuwen et al., 2009). The RPN value is obtained by multiplying the value of the three parameters. Risks with the highest RPN values are assumed to be important risks and should get high priority handling compared to risks with low RPN values (Sankar and Prabhu, 2001). Tables 1-3 provide tips for estimating the numbers $\mathrm{O}, \mathrm{S}$ and $\mathrm{D}$.

The final stage of FMEA analysis is to identify improvement actions - for failure modes with the highest risk priority number, it should be determined which corrective or preventive actions should be taken to reduce the risk of their occurrence. Improvement activities should also include specific deadlines for their implementation, as well as a list of employees responsible for their implementation. After a specified period of time, potential failures detected should be re-analysed in order to determine whether the planned activities have delivered the expected results (Gerber, 2017). If it is not possible to completely eliminate the cause of the failures, actions are taken to increase their ability to detect them or reduce the negative impact of their occurrence. Implementation of the recommended corrective actions should be continuously monitored and their effects verified (Hąbek, 2017). 


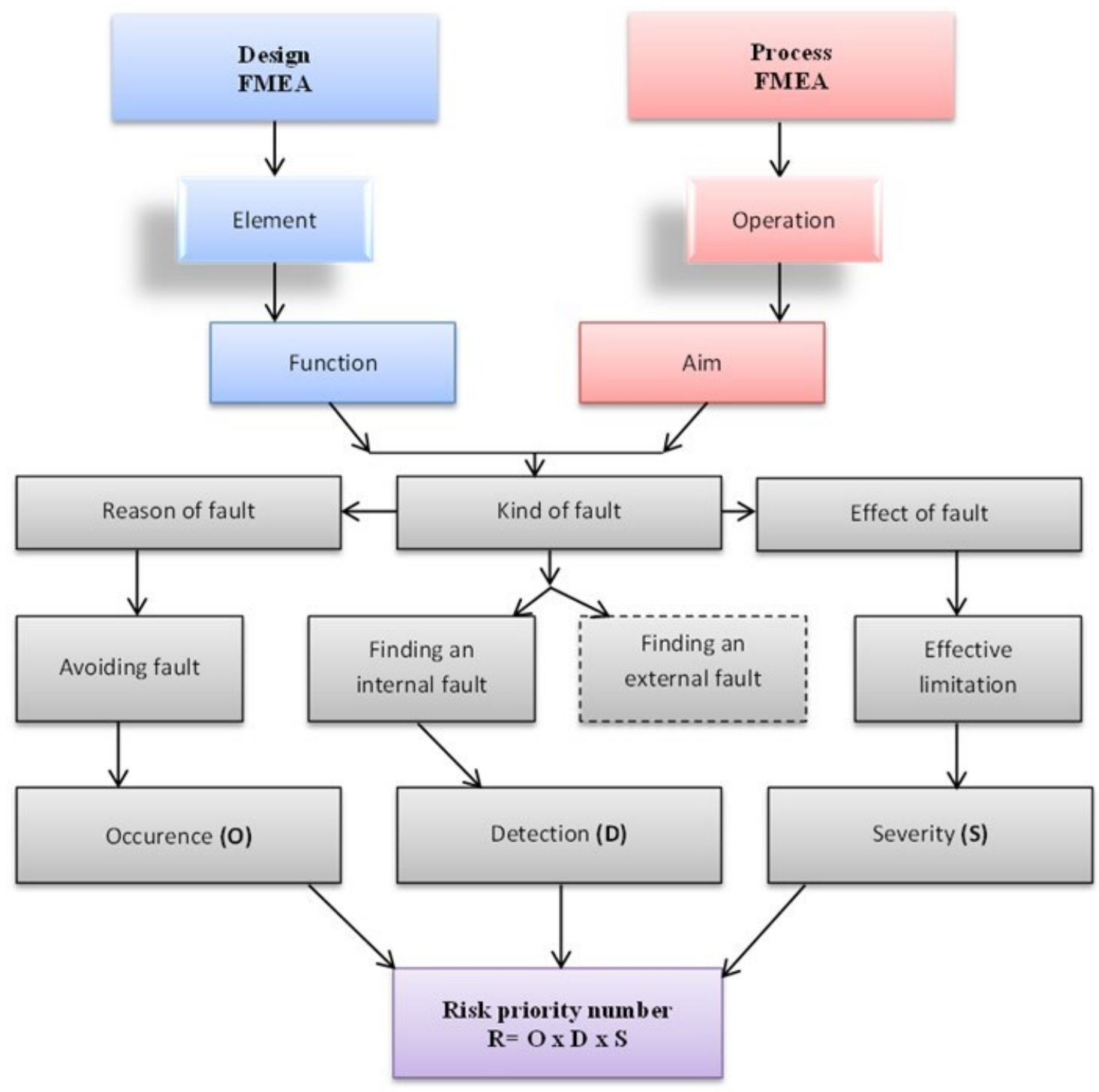

Figure 1. Scheme of FMEA method. Adapted from: "Analiza FMEA - zasady, komentarze, arkusze" by A. Folejewska. Copyright 2010 by Verlag Dashofer Sp. z o.o., Warsaw.

\section{Table 1.}

Guidelines for determining the $O$ indicator

\begin{tabular}{|c|c|c|}
\hline Occurrence & The defect may occur & $\mathbf{O}$ \\
\hline Unlikely & Less than 1 in 1000000 items. & 1 \\
\hline Very seldom & Not more than 1 in 20000 items & 2 \\
\hline Seldom & Not more than 1 in 4000 items & 3 \\
\hline \multirow{3}{*}{ Average } & Not more than 1 in 1000 items & 4 \\
\hline & Not more than 1 in 400 items & 5 \\
\hline & Not more than 1 in 80 items & 6 \\
\hline \multirow{2}{*}{ Often } & Not more than 1 in 40 items & 7 \\
\hline & Not more than 1 in 20 items & 8 \\
\hline \multirow{2}{*}{ Very often } & Not more than 1 in 8 items & 9 \\
\hline & Not more than 1 in 2 items & 10 \\
\hline
\end{tabular}

Adapted from: "Analiza FMEA- zasady, komentarze, arkusze" by A. Folejewska. Copyright 2010 by Verlag Dashofer Sp. z o.o., Warsaw. 
Table 2.

Guidelines for determining the $S$ indicator

\begin{tabular}{|c|c|c|}
\hline Severity & The importance of the defect for the customer & $\mathbf{S}$ \\
\hline Very low & $\begin{array}{l}\text { The customer does not notice the defect. The defect has no effect on the use of the } \\
\text { product. }\end{array}$ & 1 \\
\hline Low & $\begin{array}{l}\text { The defect may cause slight difficulties. It may also cause a moderate deterioration of the } \\
\text { product's properties. }\end{array}$ & $2-3$ \\
\hline Average & $\begin{array}{l}\text { The occurrence of a defect will cause limited customer dissatisfaction, as well as he will } \\
\text { notice the defects of a product that does not meet his needs. }\end{array}$ & $4-6$ \\
\hline Large & $\begin{array}{l}\text { The appearance of a defect will cause customer dissatisfaction. The customer will } \\
\text { demand its repair. }\end{array}$ & $7-8$ \\
\hline $\begin{array}{l}\text { Very } \\
\text { large }\end{array}$ & $\begin{array}{l}\text { The defect will cause great customer dissatisfaction and may expose the company to } \\
\text { high costs of repair. }\end{array}$ & 9 \\
\hline $\begin{array}{l}\text { Extra } \\
\text { large }\end{array}$ & $\begin{array}{l}\text { The occurrence of a defect is very important for the customer. A defect may endanger } \\
\text { the safety of customers, as well as violate applicable laws. }\end{array}$ & 10 \\
\hline
\end{tabular}

Adapted from: "Analiza FMEA- zasady, komentarze, arkusze" by A. Folejewska. Copyright 2010 by Verlag Dashofer Sp. z o.o., Warsaw.

Table 3.

Guidelines for determining the D indicator

\begin{tabular}{|c|c|c|}
\hline Detection & Possibility of detection of the defect & D \\
\hline Very high & $\begin{array}{c}\text { The probability of detecting a defect is very high, reaching 100\%. There is adequate } \\
\text { protection. }\end{array}$ & $1-2$ \\
\hline High & Relatively low probability of not detecting the defect. Potential defect is quite visible. & $3-4$ \\
\hline Average & $\begin{array}{c}\text { There is an average probability of not detecting the defect. The control process may be } \\
\text { slightly difficult. }\end{array}$ & $5-6$ \\
\hline Low & The risk of not detecting the defect is quite high. Symptoms of the appearance of the \\
defect are imperceptible. & $7-8$ \\
\hline Very low & $\begin{array}{c}\text { There is a very high probability that the defect will not be detected. The defect may be } \\
\text { invisible. }\end{array}$ & $9-10$ \\
\hline
\end{tabular}

Adapted from: "Analiza FMEA- zasady, komentarze, arkusze" by A. Folejewska. Copyright 2010 by Verlag Dashofer Sp. z o.o., Warsaw.

\section{Characteristics of the tested object}

The article presents an analysis of potential construction defects on the example of a guttering system produced by a company located in the Podkarpackie province. This system is shown in Figure 2. It consists of 11 separate types of elements:

- horizontal gutters,

- box mitre,

- gutter end cap,

- drop outlet,

- regular hanger,

- downspout,

- mesh gutter guard,

- pipe strap fastener, 
- downspout adapter,

- elbow,

- pipe strap.

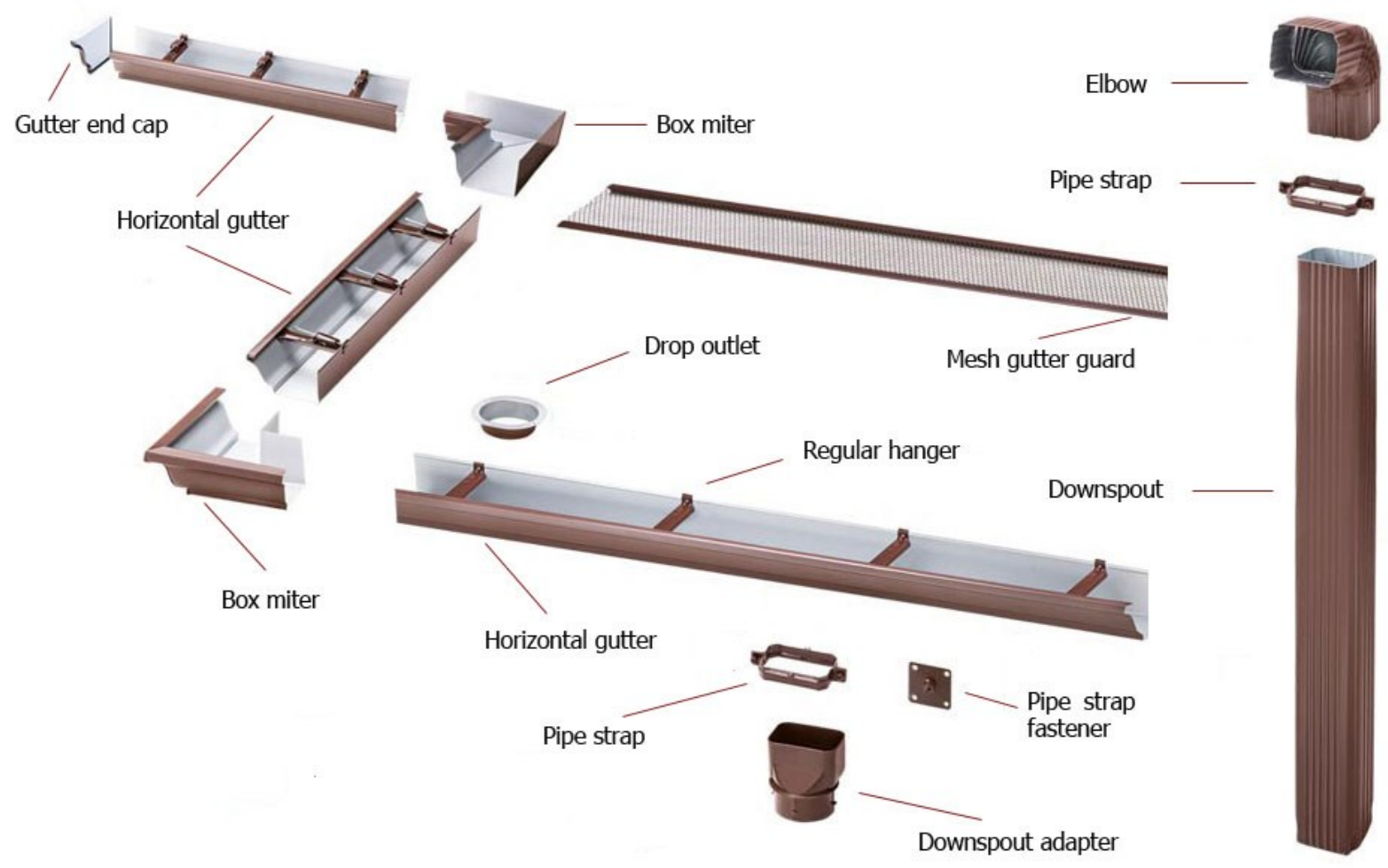

Figure 2. Scheme of guttering system. Adapted from: http://rynni.pl/system-rynnowy.html.

The material used for the production of the analysed guttering system was high quality aluminium sheet coated with acrylic paints. With this solution, the paint does not chip off and no other defects appear during its bending in the machine. It is also possible to use steel sheet. A cornice profile is a characteristic profile for the analysed system, while downspouts usually have a rectangular shape. Installation of these gutters is carried out using special regular hangers. They are invisible from below and, as a result, increase the aesthetics of the entire solution. The system is easy to install.

The presented solutions are characterised by high durability, and thanks to the materials used, the rainwater drainage system does not corrode and is resistant to extreme temperatures, which are much higher than in the case of gutters made of PVC.

\section{Results and discussion}

The results of the conducted research are shown in Table 4. The individual columns list the names of the elements constituting the product and the functions they perform. The potential defects that may appear in the product components are then specified, as well as the effects of 
their occurrence. The next step was to evaluate individual defects with a number between 1 and 10 , taking into account three criteria: probability of occurrence of the defect, importance of the defect for the customer, potential defect detection by the manufacturer. These assessments are the basis for calculating the risk priority number. The minimum RPN value adopted by the company, above which corrective actions should be proposed and implemented, was 110 .

Table 4.

Design FMEA of guttering system

\begin{tabular}{|c|c|c|c|c|c|c|c|c|c|}
\hline No. & $\begin{array}{l}\text { Name of } \\
\text { element }\end{array}$ & Function & Defect & Effect & $\begin{array}{l}\text { Control } \\
\text { systems }\end{array}$ & $\mathbf{O}$ & D & $\mathbf{S}$ & $\mathbf{R}$ \\
\hline \multirow{6}{*}{1} & \multirow{6}{*}{$\begin{array}{l}\text { Horizontal } \\
\text { gutter }\end{array}$} & \multirow{6}{*}{$\begin{array}{c}\text { Rainwater } \\
\text { drainage }\end{array}$} & $\begin{array}{l}\text { Gutter dimension } \\
\text { too long }\end{array}$ & $\begin{array}{l}\text { The need for } \\
\text { additional } \\
\text { processing }\end{array}$ & $\begin{array}{c}\text { Element } \\
\text { measurement }\end{array}$ & 6 & 2 & 7 & 84 \\
\hline & & & $\begin{array}{l}\text { Gutter dimension } \\
\text { too short }\end{array}$ & Material loss & $\begin{array}{c}\text { Element } \\
\text { measurement }\end{array}$ & 7 & 2 & 9 & 126 \\
\hline & & & $\begin{array}{c}\text { The possibility of } \\
\text { scratches }\end{array}$ & $\begin{array}{c}\text { Coated surface } \\
\text { damage }\end{array}$ & Visual control & 5 & 3 & 7 & 105 \\
\hline & & & \multirow{2}{*}{$\begin{array}{c}\text { Shape } \\
\text { incompatibility }\end{array}$} & $\begin{array}{l}\text { Difficulties or } \\
\text { inability to } \\
\text { assemble }\end{array}$ & $\begin{array}{l}\text { Sampling } \\
\text { inspection }\end{array}$ & 2 & 2 & 8 & 32 \\
\hline & & & & Material loss & $\begin{array}{c}\text { Sampling } \\
\text { inspection }\end{array}$ & 2 & 6 & 6 & 72 \\
\hline & & & $\begin{array}{l}\text { Surface damage } \\
\text { (cracks, chips, } \\
\text { shards, etc.) }\end{array}$ & $\begin{array}{l}\text { Possibility of } \\
\text { corrosion }\end{array}$ & Visual control & 6 & 5 & 8 & 240 \\
\hline \multirow{3}{*}{2} & \multirow{3}{*}{$\begin{array}{l}\text { Gutter end } \\
\text { cap }\end{array}$} & \multirow{3}{*}{$\begin{array}{l}\text { End of the } \\
\text { gutter }\end{array}$} & $\begin{array}{c}\text { Wrong size of } \\
\text { element }\end{array}$ & $\begin{array}{c}\text { Inability to } \\
\text { assemble }\end{array}$ & $\begin{array}{l}\text { Sampling } \\
\text { inspection }\end{array}$ & 3 & 5 & 7 & 105 \\
\hline & & & $\begin{array}{l}\text { The possibility of } \\
\text { scratches }\end{array}$ & $\begin{array}{c}\text { The weakening } \\
\text { of anti-corrosive } \\
\text { properties }\end{array}$ & Visual control & 4 & 4 & 6 & 965 \\
\hline & & & $\begin{array}{l}\text { Element damage } \\
\text { (e.g. bending) }\end{array}$ & $\begin{array}{l}\text { Unaesthetic } \\
\text { appearance }\end{array}$ & Visual control & 4 & 3 & 5 & 60 \\
\hline \multirow{3}{*}{3} & \multirow{3}{*}{ Box mitre } & \multirow{3}{*}{$\begin{array}{l}\text { Connecting } \\
\text { horizontal } \\
\text { gutters }\end{array}$} & $\begin{array}{l}\text { Low quality of } \\
\text { manufactured } \\
\text { item }\end{array}$ & $\begin{array}{c}\text { Shorter } \\
\text { component life }\end{array}$ & $\begin{array}{l}\text { Sampling } \\
\text { inspection }\end{array}$ & 2 & 3 & 8 & 48 \\
\hline & & & $\begin{array}{l}\text { Surface damage } \\
\text { (abrasion marks, } \\
\text { scratches, etc.) }\end{array}$ & $\begin{array}{l}\text { Lower material } \\
\text { strength }\end{array}$ & Visual control & 3 & 5 & 6 & 90 \\
\hline & & & $\begin{array}{c}\text { Shape } \\
\text { incompatibility }\end{array}$ & $\begin{array}{l}\text { Inability to } \\
\text { assembly, } \\
\text { leakage }\end{array}$ & $\begin{array}{l}\text { Sampling } \\
\text { inspection }\end{array}$ & 4 & 6 & 6 & 144 \\
\hline \multirow{3}{*}{4} & \multirow{3}{*}{$\begin{array}{l}\text { Regular } \\
\text { hanger }\end{array}$} & \multirow{3}{*}{$\begin{array}{l}\text { Fastening } \\
\text { construction }\end{array}$} & $\begin{array}{l}\text { Possibility of } \\
\text { cracks }\end{array}$ & $\begin{array}{c}\text { Danger of } \\
\text { structural } \\
\text { detachment }\end{array}$ & Visual control & 5 & 6 & 5 & 150 \\
\hline & & & Surface porosity & $\begin{array}{l}\text { Unaesthetic } \\
\text { appearance }\end{array}$ & $\begin{array}{l}\text { Sampling } \\
\text { inspection }\end{array}$ & 5 & 3 & 4 & 60 \\
\hline & & & $\begin{array}{l}\text { Incorrect } \\
\text { (crooked) } \\
\text { installation }\end{array}$ & $\begin{array}{l}\text { Impossible or } \\
\text { unaesthetic } \\
\text { assembly }\end{array}$ & Lack & 3 & 3 & 5 & 45 \\
\hline
\end{tabular}


Cont. table 4.

\begin{tabular}{|c|c|c|c|c|c|c|c|c|c|}
\hline \multirow{2}{*}{5} & \multirow{2}{*}{ Drop outlet } & \multirow{2}{*}{$\begin{array}{l}\text { Connecting } \\
\text { the horizontal } \\
\text { gutter with } \\
\text { the } \\
\text { downspout }\end{array}$} & Surface damages & $\begin{array}{l}\text { Installation } \\
\text { difficulties }\end{array}$ & Visual control & 3 & 4 & 5 & 60 \\
\hline & & & $\begin{array}{l}\text { Taking incorrect } \\
\text { tolerances }\end{array}$ & $\begin{array}{l}\text { No assembly } \\
\text { possible }\end{array}$ & Lack & 1 & 8 & 7 & 56 \\
\hline \multirow{4}{*}{6} & \multirow{4}{*}{ Downspout } & \multirow{4}{*}{$\begin{array}{l}\text { Drainage of } \\
\text { excess water }\end{array}$} & $\begin{array}{l}\text { Gutter dimension } \\
\text { too long }\end{array}$ & $\begin{array}{c}\text { The element } \\
\text { needs to be cut } \\
\text { again }\end{array}$ & $\begin{array}{c}\text { Element } \\
\text { measurement } \\
\text { (random) }\end{array}$ & 3 & 3 & 4 & 36 \\
\hline & & & $\begin{array}{l}\text { Gutter dimension } \\
\text { too short }\end{array}$ & Material costs & $\begin{array}{c}\text { Element } \\
\text { measurement } \\
\text { (random) }\end{array}$ & 4 & 3 & 5 & 60 \\
\hline & & & $\begin{array}{l}\text { Element damage, } \\
\text { e.g. dents }\end{array}$ & $\begin{array}{l}\text { Unaesthetic } \\
\text { appearance }\end{array}$ & Visual control & 3 & 2 & 8 & 48 \\
\hline & & & $\begin{array}{l}\text { Shape faults, e.g. } \\
\text { effect of riveting } \\
\text { process }\end{array}$ & $\begin{array}{c}\text { Installation } \\
\text { difficulties, lack } \\
\text { of being } \\
\text { leakproof }\end{array}$ & $\begin{array}{l}\text { Sampling } \\
\text { inspection }\end{array}$ & 5 & 7 & 7 & 245 \\
\hline \multirow{2}{*}{7} & \multirow{2}{*}{$\begin{array}{l}\text { Downspout } \\
\text { adapter }\end{array}$} & \multirow{2}{*}{$\begin{array}{l}\text { Connecting } \\
\text { horizontal } \\
\text { pipes with the } \\
\text { downspout }\end{array}$} & $\begin{array}{c}\text { Surface damage } \\
\text { (cracks, dents } \\
\text { etc.) }\end{array}$ & $\begin{array}{l}\text { Unaesthetic } \\
\text { appearance, } \\
\text { reduction of } \\
\text { performance }\end{array}$ & Visual control & 3 & 2 & 7 & 42 \\
\hline & & & $\begin{array}{l}\text { Shape faults of } \\
\text { hole diameter }\end{array}$ & $\begin{array}{c}\text { Installation } \\
\text { difficulties, } \\
\text { possible lack of } \\
\text { being leakproof }\end{array}$ & $\begin{array}{l}\text { Sampling } \\
\text { inspection }\end{array}$ & 2 & 5 & 7 & 70 \\
\hline \multirow{4}{*}{8} & \multirow{4}{*}{$\begin{array}{l}\text { Mesh gutter } \\
\text { guard }\end{array}$} & \multirow{4}{*}{$\begin{array}{c}\text { Gutter } \\
\text { protection } \\
\text { against leaves }\end{array}$} & $\begin{array}{c}\text { The mesh } \\
\text { dimensions are } \\
\text { too large }\end{array}$ & $\begin{array}{c}\text { The element } \\
\text { needs to be cut } \\
\text { again }\end{array}$ & Visual control & 6 & 2 & 7 & 84 \\
\hline & & & $\begin{array}{c}\text { The mesh } \\
\text { dimensions are } \\
\text { too small }\end{array}$ & Material costs & Visual control & 5 & 2 & 8 & 80 \\
\hline & & & $\begin{array}{c}\text { Shape } \\
\text { incompatibility, } \\
\text { e.g. mesh } \\
\text { bending }\end{array}$ & $\begin{array}{l}\text { Unaesthetic } \\
\text { appearance, loss } \\
\text { of functionality }\end{array}$ & Lack & 2 & 6 & 7 & 84 \\
\hline & & & $\begin{array}{l}\text { Damage to the } \\
\text { mesh surface, } \\
\text { e.g. in the form } \\
\text { of cracks }\end{array}$ & $\begin{array}{l}\text { Reduction of } \\
\text { corrosion } \\
\text { resistance }\end{array}$ & $\begin{array}{l}\text { Sampling } \\
\text { inspection }\end{array}$ & 5 & 6 & 8 & 240 \\
\hline \multirow{5}{*}{9} & \multirow{5}{*}{$\begin{array}{l}\text { Pipe strap } \\
\text { fastener }\end{array}$} & \multirow{5}{*}{$\begin{array}{l}\text { Fastening the } \\
\text { downspout to } \\
\text { the façade }\end{array}$} & $\begin{array}{c}\text { The diameter of } \\
\text { the holes is too } \\
\text { large }\end{array}$ & $\begin{array}{l}\text { Material costs, } \\
\text { replacement of } \\
\text { the element }\end{array}$ & $\begin{array}{l}\text { Sampling } \\
\text { inspection }\end{array}$ & 3 & 3 & 7 & 63 \\
\hline & & & $\begin{array}{c}\text { The diameter of } \\
\text { the holes is too } \\
\text { small }\end{array}$ & $\begin{array}{l}\text { The need for } \\
\text { reaming }\end{array}$ & $\begin{array}{l}\text { Sampling } \\
\text { inspection }\end{array}$ & 3 & 2 & 8 & 48 \\
\hline & & & $\begin{array}{c}\text { Incorrect } \\
\text { placement of } \\
\text { holes }\end{array}$ & $\begin{array}{c}\text { Material losses, } \\
\text { purchase of new } \\
\text { items }\end{array}$ & $\begin{array}{c}\text { Element } \\
\text { measurement } \\
\text { (random) }\end{array}$ & 3 & 7 & 4 & 84 \\
\hline & & & Threading faults & $\begin{array}{l}\text { Difficult or } \\
\text { impossible } \\
\text { installation }\end{array}$ & Lack & 4 & 8 & 8 & 256 \\
\hline & & & $\begin{array}{c}\text { Surface damage, } \\
\text { e.g. cracks }\end{array}$ & $\begin{array}{c}\text { Unaesthetic } \\
\text { appearance, loss } \\
\text { of functionality }\end{array}$ & Visual control & 4 & 5 & 5 & 100 \\
\hline
\end{tabular}


Cont. table 4.

\begin{tabular}{|c|c|c|c|c|c|c|c|c|c|}
\hline \multirow[t]{2}{*}{10} & \multirow[t]{2}{*}{ Elbow } & \multirow{2}{*}{$\begin{array}{l}\text { Changing the } \\
\text { flow direction }\end{array}$} & $\begin{array}{l}\text { Shape errors, e.g. } \\
\text { incorrect bending }\end{array}$ & $\begin{array}{c}\text { Installation } \\
\text { difficulties, } \\
\text { leakage }\end{array}$ & $\begin{array}{l}\text { Sampling } \\
\text { inspection }\end{array}$ & 3 & 4 & 7 & 84 \\
\hline & & & $\begin{array}{c}\text { Surface damage, } \\
\text { e.g. scratches }\end{array}$ & $\begin{array}{l}\text { Unaesthetic } \\
\text { appearance }\end{array}$ & Visual control & 3 & 3 & 7 & 63 \\
\hline \multirow[t]{2}{*}{11} & \multirow[t]{2}{*}{ Pipe strap } & \multirow[t]{2}{*}{$\begin{array}{l}\text { Downspout } \\
\text { maintenance }\end{array}$} & $\begin{array}{c}\text { Surface damage, } \\
\text { e.g. dents }\end{array}$ & $\begin{array}{l}\text { Unaesthetic } \\
\text { appearance, } \\
\text { reduction of anti- } \\
\text { corrosion } \\
\text { properties }\end{array}$ & Visual control & 3 & 5 & 6 & 90 \\
\hline & & & $\begin{array}{l}\text { Mismatched hole } \\
\text { diameters }\end{array}$ & $\begin{array}{l}\text { Installation } \\
\text { difficulties }\end{array}$ & $\begin{array}{l}\text { Sampling } \\
\text { inspection }\end{array}$ & 3 & 4 & 7 & 84 \\
\hline
\end{tabular}

Seven such undesirable states have been identified. At the beginning, the company should take steps to exclude these defects. The Ishikawa diagram was used to identify the sources of problems.

\section{Problem 1: The dimension is too short}

A common problem connected with this defect is the lack of calibration of the measuring devices. An employee cannot perform his work accurately without the right tools. A solution to the problem could be the introduction of periodic device calibrations. Thanks to this, the measured distances will be reliable. Current procedures should be updated and should include calibration methods and deadlines.

\section{Problem 2: Damaged surface}

Damage to the gutter surface is also a constant problem. This is a gradual loss of material from the surface layer. Gutters often blocked the transport route through inadequate storage. The simplest solution with low financial cost is to reorganise the warehouse. This would help to designate a suitable place to store products, at the same time avoiding contact with other materials. An even better solution could be expansion of the warehouse. However, in this case, the costs would be higher.

\section{Problem 3: Shape incompatibility}

Due to shape incompatibility, a rainwater drainage system loses functionality. Leaking water in some places is a common problem. Employees who carelessly do their work have a big impact on this. Thanks to systematic training of employees, this problem can be solved, and the company will save time and money. Continuous improvement of worker qualifications can increase the company's profits. Staff can also learn about new working methods in other to reduce the time of work.

\section{Problem 4: Cracks}

Material defects arise both during the production process and during operation. The reduced strength parameters of the material can strongly affect the strength of the entire structure. Cracks are an important factor when it comes to strength. A well-chosen material must undergo a series of strength tests. It is possible that after this analysis, the material from which regular hangers are made should be replaced. 


\section{Problem 5: Shape faults, e.g. effect of the riveting process}

Without proper riveting, the downspout does not fulfil its functions. It is exposed to leakage. Controls carried out in the company are too rare, and this is why a large number of downspouts leave the workplace with a visible and significant defect. This situation requires immediate improvement in the company. The amount of control during the production process is not sufficient. At present, only $10 \%$ of the daily products are inspected. To improve this aspect, controls should be carried out a minimum of $30 \%$ of the time.

\section{Problem 6: Damage to the mesh surface, e.g. in the form of cracks}

Most of these elements are made of metal, so the probability of corrosion is very high. Thanks to the proper application of an anti-corrosion coatings, it is possible to prevent a large number of faults and future complaints. The most important features during this process are focus and accuracy. Improper equipment can also have a big impact. Buying new equipment is an expensive investment. However, by wanting to provide services at the highest level, a company should buy newer equipment.

\section{Problem 7: Threading faults}

To fulfil customers' expectations, the product must be made of the highest quality. All elements must match and form a complete structure. In case of improper threading, it will not be possible to join the structure elements. The basic problem of tapping is the wrong selection of screw-taps. To solve this, screw-tap application tables should be hung at the workplace. The employees should have easy and direct access to it. An additional solution could be employee training on the selection of screw-taps.

The use of the FMEA method and Ishikawa diagram contributed to the detection of defects and their root causes. On this basis, corrective and preventive actions have been established. This should contribute to improving the quality of the guttering structure. The identified defects and their root causes, together with the proposal of corrective and preventive actions, are summarised in Table 5.

\section{Table 5.}

List of problems, root of the problems and proposed actions

\begin{tabular}{|c|l|l|l|}
\hline No. & \multicolumn{1}{|c|}{ Problem } & \multicolumn{1}{|c|}{ Root of the problem } & \multicolumn{1}{c|}{ Proposed actions } \\
\hline $\mathbf{1}$ & $\begin{array}{l}\text { The dimension is too } \\
\text { short }\end{array}$ & $\begin{array}{l}\text { Lack of calibration of } \\
\text { measuring devices }\end{array}$ & Periodic calibration of devices \\
\hline $\mathbf{2}$ & Damaged surface & $\begin{array}{l}\text { Wrong warehouse } \\
\text { organisation }\end{array}$ & $\begin{array}{l}\bullet \\
\bullet \quad \text { warehouse reorganisation } \\
\text { warehouse expansion }\end{array}$ \\
\hline $\mathbf{3}$ & Shape incompatibility & Lack of motivation & Systematic staff training \\
\hline $\mathbf{4}$ & Cracks & Incorrectly selected material & Material strength tests \\
\hline $\mathbf{5}$ & $\begin{array}{l}\text { Shape faults, e.g. effect } \\
\text { of riveting process }\end{array}$ & Controls too rare & Increase the number of controls \\
\hline $\mathbf{6}$ & $\begin{array}{l}\text { Damage to the mesh } \\
\text { surface, e.g. in the } \\
\text { form of cracks }\end{array}$ & Outdated technology & Purchase of new equipment \\
\hline $\mathbf{7}$ & $\begin{array}{l}\text { Threading faults } \\
\mathbf{n}\end{array}$ & Incorrect screw-taps & $\begin{array}{l}\text { Application table at the workplace } \\
\text { Staff training }\end{array}$ \\
\hline
\end{tabular}


Incorrect riveting processes turned out to be one of the most significant problems. This defect is caused by rare joining controls. The number of controls should be increased. A big problem is also surface damage of the gutter. Such defects are usually caused by an improperly managed warehouse. The company should reorganise the warehouse and properly protect its products against mechanical damage.

A problem that generates a large number of defects is also improperly made threads in the pipe strap fastener. Defects occur as a result of improper screw-tap selection. With low workload and low financial effort, the problem can be solved by properly marking the screwtaps. Screw-tap application tables should also be hung at the workplace. In addition, staff training would increase their knowledge concerning this topic.

A failure that requires a lot of financial effort from the company is an improperly applied anti-corrosive coating on the mesh gutter guard. The cause of defects is outdated technology. To solve this problem, the company should purchase newer equipment. This would make the work of employees easier, as well as improve the quality of the final product.

\section{Conclusions}

The FMEA method has the potential to anticipate and prevent problems, reduce costs, shorten product development times and achieve safe and highly reliable products and processes.

The presented analysis showed the critical elements of the structure, which should be taken into account by a company during the design process of a guttering system. For identified failures, improvements were proposed, and after their implementation, an acceptable level of risk was achieved.

A significant part of the problems can be solved by conducting staff trainings. This will increase their qualifications, as well as raise the reputation and position of the company.

With a relatively low financial cost, the company can reduce the risk of failures by organising the warehouse, calibrating devices and more frequent control of the staff.

With a much larger financial investment, a company can improve the quality of products by purchasing more modern machinery and equipment. It will also make the work easier for operators. 


\section{References}

1. Blong, R. (2004). Residential building damage and natural perils: Australian examples and issues. Building Research and Information, Vol. 32(5), 379-390, doi: 10.1080/ 0961321042000221007.

2. Florczak, P. (2014). Metalowe systemy rynnowe. Inżynier budownictwa. Retrieved from: http://www.inzynierbudownictwa.pl/technika,materialy_i_technologie,artykul,metalowe_s ystemy_rynnowe, 7661, 18.04.2020.

3. Folejewska, A. (2010). Analiza FMEA - zasady, komentarze, arkusze. Warszawa: Wydawnictwo Verlag Dashofer Sp. z o.o.

4. Greber, T. (2017). Analiza FMEA. Kompendium wiedzy praktycznej (materiały pomocnicze do warsztatów FMEA). Wrocław: PROQUAL Management Institute.

5. Hąbek, P. (2017). The concept of using FMEA method for the purpose of sustainable manufacturing. Systemy Wspomagania w Inżynierii Produkcji, Vol. 6(4), 49-55. Retrieved from: http://wydawnictwo.panova.pl/attachments/article/598/R6.pdf, 18.04.2020.

6. Półtorak, M. (2010). Wybór systemu rynnowego. Inżynier budownictwa. Retrieved from: http://www.inzynierbudownictwa.pl/technika,materialy_i_technologie,artykul,wybor_syst emu_rynnowego,4082, 18.04.2020.

7. Rusecki, A. (2018). Praktyczne zastosowanie metody FMEA na przykładzie produkcji koła pasowego w wybranym przedsiębiorstwie. Quality Production Improvement, Vol. 1(8), 7-18. Retrieved from: https://www.qpi-journal.pl/EN/files/2018_8_01.pdf, 18.04.2020.

8. Rynni - Gutter System. Available online http://rynni.pl/en/gutter-system.html, 18.04.2020.

9. Sankar, R.N., Prabhu, B.S. (2001). Modified approach for prioritization of failures in a system failure mode and effects analysis. International Journal of Quality \& Reliability Management, Vol. 18(3), 324-336. doi: 10.1108/02656710110383737.

10. Spekkers, M.H., Clemens, F., ten Veldhuis, J.A. (2015). On the occurrence of rainstorm damage based on home insurance and weather data. Natural Hazards and Earth System Sciences, Vol. 15, 261-272, doi: 10.5194/nhess-15-261-2015.

11. Tavukcuoglu, A., Duzgunes, A., Demirci, S., Caner-Saltık, E.N. (2007). The assessment of a roof drainage system for an historical building. Building and Environment. Vol. 42(7), 2699-2709. doi: 10.1016/j.buildenv.2006.07.012.

12. van Leeuwen, J.F., Nauta, M.J., de Kaste, D., Odekerken-Rombouts, Y.M.C.F., Oldenhof, M.T., Vredenbregt, M.J., Barends, D.M. (2009). Risk analysis by FMEA as an element of analytical validation. Journal of Pharmaceutical and Biomedical Analysis, Vol. 50(5), 1085-1087. doi: 10.1016/j.jpba.2009.06.049.

13. Verstraten, L., Lucke, T., O'Loughlin, G. (2017). Comparing empirical water depth observations of a box gutter roof drainage system to three different international design guidelines. Journal of Building Engineering, Vol. 12, 178-187. doi: 10.1016/ j.jobe.2017.06.004. 